ISSN 1392-3196 / e-ISSN 2335-8947

Zemdirbyste-Agriculture, vol. 104, No. 2 (2017), p. 157-164

DOI 10.13080/z-a.2017.104.020

\title{
Response of bi-parental spring barley populations to cultivation in organic and conventional farming systems
}

\author{
Ieva MEŽAKA ${ }^{1}$, Indra LOČMELE ${ }^{1}$, Dainis RUN̦ĢIS ${ }^{2}$, Linda LEGZDIN̦A ${ }^{1}$ \\ ${ }^{1}$ Institute of Agricultural Resources and Economics \\ 2 Zinatnes, Priekuli, Latvia \\ E-mail: ieva.mezaka@arei.lv \\ ${ }^{2}$ Latvian State Forest Research Institute "Silava" \\ 111 Rigas, Salaspils, Latvia
}

\begin{abstract}
The organic farming sector is increasing in importance and requires varieties with stable yield and adapted to organic growing conditions. Heterogeneous populations of self-pollinating crops can potentially offer an advantage over currently used homogeneous varieties. The aim of the study was to compare yield, grain quality traits and genetic diversity in two bi-parental spring barley (Hordeum vulgare L.) populations over the course of six to eight generations. Populations were made by simple crosses, divided as subpopulations in F4 generation and then cultivated in parallel at two organic and two conventional sites for consecutive five generations. After that all subpopulations were compared in joint field trial at one organic and one conventional site to determine if they had divergent grain yield and quality properties. The genetic diversity of two subpopulations from each cross was studied in the seventh cultivation season using nine SSR (simple sequence repeat) markers.

Mixed-effect modelling showed that cultivation environment was significant for grain yield and not significant for grain quality traits. Cultivation of subpopulations derived from the two crosses over six generations concurrently under conventional and organic conditions did not significantly change genetic diversity or allelic composition as assessed by SSR markers - each pair of subpopulations from the same cross were similar in both environments with one population showing a small drift. Similar proportion of alleles contributed by each parent was observed thus indicating that none of the parental varieties was preferred by selection.
\end{abstract}

Key words: bi-parental populations, genetic adaptation, Hordeum vulgare, natural selection, SSR markers.

\section{Introduction}

During the last century, intensive barley breeding has resulted in the development of genetically uniform varieties, with wide adaptation to conventional farming systems with high inputs of mineral fertilizers and pesticides (Bellucci et al., 2013). High input agricultural systems are becoming unsustainable due to a decrease in the availability of resources, such as water, oil and phosphorus, which is further exacerbated by human population growth, required increasing levels of agricultural production (Fess et al., 2011). Attempts to create single-genotype varieties have led to a reduction in genetic diversity of crop plants ( $\mathrm{Li}$ et al., 2014). Genetic diversity is essential for the adaptation of both wild and cultivated species to future environmental changes, and is increasingly recognised as a crucial aspect of agricultural systems, especially considering the impacts of climate change (Barrett, Schluter, 2008; Mercer, Perales, 2010; Raggi et al., 2015). In Europe, genetically uniform crop varieties started to replace more genetically heterogeneous landraces in the 1920 s, with the replacement rate increasing after the end of World War II. As an alternative to uniform varieties, genetically diverse population varieties that undergo natural selection and are able to adapt to fluctuations in environmental conditions can be utilised. Populations (landraces) that undergo both natural selection and farmer selection have been shown to increase yield, disease resistance, genetic diversity and adaptability over time (Murphy et al., 2005). Genetic diversity within cultivated varieties and the resulting ability to adapt to heterogeneous and fluctuating environments in time and space is particularly pertinent to organic and low-input agricultural systems (Østergård et al., 2009).

Changes in genetic diversity in cereal populations subjected to natural selection have been assessed in several previous studies. Restriction fragment length polymorphism (RFLP) markers were used to compare allelic frequencies of subpopulations derived

Please use the following format when citing the article:

Mežaka I., Ločmele I., Ruņgis D., Legzdiņa L. 2017. Response of bi-parental spring barley populations to cultivation in organic and conventional farming systems. Zemdirbyste-Agriculture, 104 (2): 157-164 DOI 10.13080/z-a.2017.104.020 
from two composite cross populations (CCPs) cultivated for ten years at four contrasting sites in France. Strong differentiation of agro-morphological traits (earliness, resistance to pathogens, etc.) was found, and RFLP diversity also showed highly significant differentiation between subpopulations, indicating that natural selection greatly influenced the development of these populations. No decrease in genetic diversity and a higher than expected heterozygosity were observed and introgression of new alleles was also detected, which was attributed to a low level of outcrossing (6\%) in wheat (Enjalbert et al., 2011). Rouselle et al. (2011) cultivated wheat populations over 12 generations and observed no loss of within population diversity and little genetic divergence of subpopulations. In a study of the genomic region surrounding the wheat semi-dwarfing gene $R h t-B 1$ a slight reduction of diversity was detected in wheat $\mathrm{CCP}$, with selection favouring individuals carrying the tall allelic form of the Rht-B1 gene (Raquin et al., 2008). A study of genetic diversity in barley using SSR markers revealed that 12 Sardinian six-rowed landraces had the same level of within population genetic diversity as a representative sample of 59 six-rowed and two-rowed modern commercial varieties (Bellucci et al., 2013). Investigation of genetic diversity in seven barley parental populations (breeding lines, landraces and varieties) and CCPs derived from these parental populations revealed evolution of populations over 13 years of cultivation and selection effects at adaptive traits and abiotic stress response loci (Raggi et al., 2015). Nevo et al. (2011) found changes in flowering time and in SSR allelic turnover over a 28 year span in wild barley and wheat populations in Israel, which were attributed to climate change. However, in a short term study cultivating one barley variety and one landrace for five generations under three scenarios of increased atmospheric $\mathrm{CO}_{2}$ concentration and increased temperature, lower yield and fewer seeds were observed when compared to controls, indicating that barley might not respond positively to rapid and strong selection in elevated $\mathrm{CO}_{2}$ concentration and increased temperature, possibly due to lack of phenotypic plasticity and ability for fast genetic change (Alemayehu et al., 2013).

An investigation of wheat CCPs subjected to natural selection in organic and conventional systems indicated that within five years of cultivation under conventional and organic management systems, characteristics for early vigour, but not allelopathy, were improved in organically-managed CCPs in comparison to conventionally-managed CCPs. An increase in plant height was observed in both management systems (Bertholdsson et al., 2016). Knapp et al. (2013) studied genetic changes using SSR markers in wheat CCPs under two conventional and two organic sites over 11 generations. Results showed that no adaptation to management or to sites could be detected, i.e. the allele frequencies did not change in significantly different ways at the four sites. To our knowledge, no investigations of changes in genetic diversity in barley populations cultivated simultaneously in organic and conventional farming environments have been published.

The aim of this study was to compare yield and grain quality traits and genetic diversity of two biparental populations cultivated in parallel in both organic and conventional environments for six to eight seasons.

\section{Materials and methods}

Spring barley populations performed in 2004 from two bi-parental cross combinations 'Primus'/'Idumeja' (P/I) and 'Anni'/'Džiugiai' (A/Dz) were used in the study. In the first cross, an old (in use since 1901), late maturing Swedish variety 'Primus' with very tall plants was crossed with an early maturing Latvian variety 'Idumeja' (released in 2001) with medium tall plants and rapid early development. In the second cross, an Estonian variety 'Anni' (released in 1993) with comparatively short plants and good yield in various growing conditions was crossed with a Lithuanian variety 'Džiugiai' (released in 1947) with tall plants and very rapid early development. F1 to F3 generations of population from each cross were cultivated in conventional conditions. Starting from the F4 generation, populations were divided into subpopulations (Table 1) and cultivated in two organic $(\mathrm{O})$ and two conventional (C) sites (location $57^{\circ} 19^{\prime} \mathrm{N}, 25^{\circ} 20^{\prime}$ E) (Table 2). Field trials for comparison of all eight subpopulations were carried out in 2012 and in 2014 (F9 and F11 generations, respectively) in the $\mathrm{O} 1$ and $\mathrm{C} 1$ sites in four replications of $12.3 \mathrm{~m}^{2}$ plots in a randomized complete block design with a seeding rate of 400 untreated viable seeds per $\mathrm{m}^{2}$. Each of the eight subpopulations was tested in both organic and conventional conditions. Plant shoot samples for DNA extraction were collected in 2013 (F10 generation).

Table 1. Denominations of subpopulations

\begin{tabular}{ccc}
\hline Cross & Site of cultivation & Denomination \\
\hline Primus/Idumeja & $\mathrm{O} 1$ & $\mathrm{P} / \mathrm{I}-\mathrm{O} 1^{*}$ \\
& $\mathrm{C} 1$ & $\mathrm{P} / \mathrm{I}-\mathrm{C} 1^{*}$ \\
& $\mathrm{O} 2$ & $\mathrm{P} / \mathrm{I}-\mathrm{O} 2$ \\
Anni/Džiugiai & $\mathrm{C} 2$ & $\mathrm{P} / \mathrm{I}-\mathrm{C} 2$ \\
& $\mathrm{O} 1$ & $\mathrm{~A} / \mathrm{Dz}-\mathrm{O} 1^{*}$ \\
& $\mathrm{C} 1$ & $\mathrm{~A} / \mathrm{Dz}-\mathrm{C} 1^{*}$ \\
& $\mathrm{O} 2$ & $\mathrm{~A} / \mathrm{Dz}-\mathrm{O} 2$ \\
& $\mathrm{C} 2$ & $\mathrm{~A} / \mathrm{Dz}-\mathrm{C} 2$ \\
\hline
\end{tabular}

$\mathrm{O}$ - organic, $\mathrm{C}$ - conventional; * - subpopulations genotyped in year 2013 (F10)

Testing was performed on Luvisol (Lv), soil properties are summarized in Table 3.

Meteorological conditions were generally favourable for barley development in both field trial years. In 2012, a high level of precipitation delayed sowing. However, the beginning of May was dry and warm (temperature in the first ten-day period was $2.3^{\circ} \mathrm{C}$ above the long term average). The remainder of the growing season was high in precipitation, with alternating warmer and cooler days. The rainfall maximum was reached in the second ten-day period of July, when it was $160 \%$ above the long term average. The average level of precipitation during the growing season was $64 \%$ above the long term average. The first and second ten-day period of July were cooler than the long term average by $2.5^{\circ} \mathrm{C}$ and $1.8^{\circ} \mathrm{C}$, respectively, whereas the first ten-day period of May and July were warmer than the long-term average by $2.1^{\circ} \mathrm{C}$ and $3.2^{\circ} \mathrm{C}$, respectively. In 2014 , sowing was done in the last ten-day period of April and no precipitation was observed during that period, but average air temperature was $2.3^{\circ} \mathrm{C}$ above the long-term average. In May and June rainfall increased $(73 \%$ and $38 \%$ above long term average), and temperature in the first and second ten-day period of June was $3.4^{\circ} \mathrm{C}$ below the long-term average, resulting in delayed plant development. In July, rainfall 
Table 2. Characteristics of crop management in cultivation (2007-2013) and field trial sites

\begin{tabular}{|c|c|}
\hline Location & Crop management \\
\hline $\begin{array}{l}\text { O1 - } \\
\text { certified organic trial field } \\
\quad(2012 \text { and 2014)* }\end{array}$ & $\begin{array}{l}\text { Precrop - green manure (legumes) } \\
\text { Fertility management }- \text { green manure in crop rotation } \\
\text { Management of diseases and pests }- \text { no } \\
\text { Management of weeds }-1 \times \text { harrowing at tillering stage }\end{array}$ \\
\hline $\begin{array}{c}\mathrm{O} 2 \\
\text { certified organic farm }\end{array}$ & $\begin{array}{l}\text { Precrop - perennial grass } \\
\text { Fertility management - farmyard manure used in precrop } \\
\text { Management of diseases and pests - no } \\
\text { Management of weeds - no }\end{array}$ \\
\hline $\begin{array}{l}\mathrm{C} 1- \\
\text { conventional breeding field } \\
(2012 \text { and 2014)* }\end{array}$ & $\begin{array}{l}\text { Precrop - potato } \\
\text { Fertility management - mineral fertilizer } \\
\mathrm{N}_{80} \mathrm{P}_{10} \mathrm{~K}_{75} \mathrm{~kg} \mathrm{ha}^{-1}(2012) \\
\mathrm{N}_{80} \mathrm{P}_{30} \mathrm{~K}_{45} \mathrm{~kg} \mathrm{ha}^{-1}(2014) \\
\text { Management of diseases - no } \\
\text { Management of pests - insecticide (2012) } \\
\text { Management of weeds - herbicide }\end{array}$ \\
\hline $\begin{array}{c}\mathrm{C} 2- \\
\text { conventional seed production field }\end{array}$ & $\begin{array}{l}\text { Precrop - potato } \\
\text { Fertility management - mineral fertilizer } \\
\mathrm{N}_{80} \mathrm{P}_{45} \mathrm{~K}_{80} \mathrm{~kg} \mathrm{ha}^{-1} \\
\text { Management of diseases - no } \\
\text { Management of pests - insecticide } \\
\text { Management of weeds - herbicide }\end{array}$ \\
\hline
\end{tabular}

Note. O - organic, $\mathrm{C}$ - conventional; * - years when field testing for comparison of all subpopulations was performed in the respective site.

Table 3. Soil agrochemical properties at organic $(\mathrm{O} 1)$ and conventional (C1) field trial sites in 2012 and 2014

\begin{tabular}{ccccc}
\hline \multirow{2}{*}{ Indices } & \multicolumn{2}{c}{2012} & \multicolumn{2}{c}{2014} \\
\cline { 2 - 5 } & $\mathrm{O} 1$ & $\mathrm{C} 1$ & $\mathrm{O} 1$ & $\mathrm{C} 1$ \\
\hline Soil pH KCL & 5.7 & 5.7 & 5.5 & 5.8 \\
Humus content \% & 2.3 & 2.7 & 2.1 & 2.3 \\
$\mathrm{~K} \mathrm{mg} \mathrm{kg}^{-1}$ & 77 & 128 & 106 & 123 \\
$\mathrm{P} \mathrm{mg} \mathrm{kg}^{-1}$ & 70 & 115 & 79 & 75 \\
\hline
\end{tabular}

was $82 \%$ below the long term average, but air temperature was higher by $2.3^{\circ} \mathrm{C}$.

Ninety six individuals from each of four spring barley subpopulations (P/I-O1, P/I-C1 A/Dz-O1 and A/ Dz-C1) (Table 1) and 20 individuals from each parental variety were genotyped. Plant shoot samples were taken randomly from individual plants in the field during the tillering stage in 2013, in the seventh generation after initiation of cultivation in the respective site. DNA was extracted using the modified protocol of Edwards et al. (1991). Nine simple sequence repeat (SSR) markers were multiplexed in three marker sets: set A (Bmag0125, Bmac0067, Bmac0032), set B (Bmag0135, WMC1E8, Bmag0173) and set C (Bmag0353, Bmac0093, Bmac0156) (Macaulay et al., 2001). The forward primer was synthesised with a 6-FAM, HEX or NED fluorescent label to allow visualisation of amplification products on a fluorescent sequencer. Multiplex polymerase chain reactions (PCRs) were performed in a total volume of reaction $20 \mu \mathrm{l}$ containing $1 \mu \mathrm{L}$ template DNA, $4 \mu \mathrm{L} 5 \mathrm{x}$ HOT FirePol ${ }^{\circledR}$ Blend Master Mix (Solis BioDyne, Estonia), $0.2 \mu \mathrm{M}$ of forward (labelled) and reverse primers. PCR conditions were as follows: $95^{\circ} \mathrm{C}$ for 15 min, 40 cycles of $95^{\circ} \mathrm{C}-20 \mathrm{sec}, 58^{\circ} \mathrm{C}$ (set A and B) or $60^{\circ} \mathrm{C}(\operatorname{set} \mathrm{C})-40 \mathrm{sec}, 72^{\circ} \mathrm{C}-60 \mathrm{sec}, 72^{\circ} \mathrm{C}-10 \mathrm{~min}$. PCR products were separated on an ABI $3100 \times 1$ capillary sequencer, and genotyped using software GeneMapper 4.0. Population genetic parameters were calculated using GenAlEx 6.5 (Peakall, Smouse, 2012).
Statistical analysis was performed in computing envinronment $R$, version 3.2.2. ( $R$ Core Team, 2015) using mixed effect models implemented in package lme 4 (Bates, Maechler, 2013). We compared the full model (with all the fixed effects in question with up to three way interactions) stepwise against reduced models without the effects in question. Year, site of cultivation and site of field trials were considered to be fixed effects, and genotype to be a random effect. In each case, we concluded that a fixed effect is significant if the difference between the likelihood of two models is significant. The most probable model was then used to calculate $p$-values using the Satterthwaite approximation, which is implemented in the package lmerTest (Kuznetsova et al., 2013).

\section{Results}

Yield in organic fields was lower than in conventional fields and in individual populations was $48 \%$ to $61 \%$ of that in conventional fields in 2012 and $75 \%$ to $81 \%$ in 2014 . The highest average yield over all field trial environments were obtained for subpopulations cultivated in $\mathrm{O} 2$ and $\mathrm{C} 2$ sites and it was lowest for subpopulations cultivated in $\mathrm{C} 1$ (for cross $\mathrm{P} / \mathrm{I}$ ) and $\mathrm{O} 1$ (for cross A/Dz) (Table 4).

All variables (testing environment, cultivation site and testing year) and their two way and three way interactions significantly affected grain yield (Table 5). Subpopulations from both crosses cultivated at the $\mathrm{O} 1$ location showed opposite tendencies in both testing years while tested in the respective O1 site: in 2012 they were the lowest yielding among subpopulations, while in 2014 they were the highest yielding; however, the differences between subpopulations were not statistically significant. The subpopulation $\mathrm{P} / \mathrm{I}-\mathrm{O} 2$ produced the highest yield in both testing years at the $\mathrm{C} 1$ site and $\mathrm{P} / \mathrm{I}-\mathrm{C} 1$ was lowest yielding in three out of four testing environments. The subpopulation A/Dz-O1 was lowest yielding in both testing environments in 2012 and highest yielding in both environments in 2014, while the yields of subpopulation $\mathrm{A} / \mathrm{Dz}-\mathrm{C} 2$ showed an opposite trend. 
Table 4. Grain yield and quality indices obtained from field trials of the eight subpopulations in organic (O1) and conventional (C1) conditions in 2012 and 2014

\begin{tabular}{|c|c|c|c|c|c|c|c|c|c|c|c|}
\hline \multirow{2}{*}{ Indices } & \multirow{2}{*}{ Year } & \multirow{2}{*}{$\begin{array}{l}\text { Field trial } \\
\text { site }\end{array}$} & \multirow{2}{*}{ Average } & \multicolumn{4}{|c|}{ 'Primus'/'Idumeja' } & \multicolumn{4}{|c|}{ 'Anni'/'Džiugiai' } \\
\hline & & & & $\mathrm{P} / \mathrm{I}-\mathrm{O} 1$ & $\mathrm{P} / \mathrm{I}-\mathrm{O} 2$ & $\mathrm{P} / \mathrm{I}-\mathrm{C} 1$ & $\mathrm{P} / \mathrm{I}-\mathrm{C} 2$ & $\mathrm{~A} / \mathrm{Dz}-\mathrm{O} 1$ & $\mathrm{~A} / \mathrm{Dz}-\mathrm{O} 2$ & $\mathrm{~A} / \mathrm{Dz}-\mathrm{C} 1$ & $\mathrm{~A} / \mathrm{Dz}-\mathrm{C} 2$ \\
\hline \multirow{4}{*}{$\begin{array}{c}\text { Grain yield } \\
\mathrm{t} \mathrm{ha}^{-1}\end{array}$} & \multirow{2}{*}{2012} & $\mathrm{C} 1$ & $4.10 \mathrm{a}$ & 4.13 & 4.20 & 3.75 & 4.19 & 3.93 & 4.25 & 3.99 & 4.32 \\
\hline & & $\mathrm{O} 1$ & $2.25 \mathrm{~b}$ & 1.99 & 2.18 & 2.21 & 2.28 & 2.02 & 2.45 & 2.43 & 2.45 \\
\hline & \multirow{2}{*}{2014} & $\mathrm{C} 1$ & $3.98 \mathrm{a}$ & 3.80 & 3.93 & 3.69 & 3.89 & 4.20 & 4.15 & 4.13 & 4.01 \\
\hline & & O1 & $3.15 \mathrm{c}$ & 3.11 & 2.96 & 2.87 & 3.08 & 3.32 & 3.30 & 3.31 & 3.28 \\
\hline \multirow{4}{*}{$\begin{array}{l}\text { Crude } \\
\text { protein } \\
\mathrm{g} \mathrm{kg}^{-1}\end{array}$} & \multirow{2}{*}{2012} & $\mathrm{C} 1$ & $128.88 \mathrm{a}$ & 126 & 125 & 130 & 127 & 134 & 131 & 130 & 128 \\
\hline & & $\mathrm{O} 1$ & $145.38 \mathrm{~b}$ & 146 & 147 & 143 & 147 & 146 & 146 & 144 & 144 \\
\hline & \multirow{2}{*}{2014} & $\mathrm{C} 1$ & $123.63 \mathrm{c}$ & 125 & 126 & 128 & 117 & 121 & 123 & 125 & 124 \\
\hline & & $\mathrm{O} 1$ & $134.63 \mathrm{~d}$ & 135 & 139 & 137 & 136 & 136 & 131 & 132 & 131 \\
\hline \multirow{4}{*}{$\begin{array}{l}\text { Starch } \\
\mathrm{g} \mathrm{kg}^{-1}\end{array}$} & \multirow{2}{*}{2012} & $\mathrm{C} 1$ & $606.13 \mathrm{a}$ & 604 & 607 & 606 & 605 & 605 & 606 & 609 & 607 \\
\hline & & O1 & $602.75 \mathrm{~b}$ & 602 & 601 & 604 & 602 & 603 & 603 & 603 & 604 \\
\hline & \multirow{2}{*}{2014} & $\mathrm{C} 1$ & $615.13 c$ & 613 & 605 & 616 & 620 & 617 & 622 & 614 & 614 \\
\hline & & $\mathrm{O} 1$ & $617.75 \mathrm{c}$ & 617 & 615 & 618 & 619 & 618 & 620 & 616 & 619 \\
\hline \multirow{4}{*}{$\begin{array}{l}\text { Volume } \\
\text { weight } \\
\mathrm{g} \mathrm{L}^{-1}\end{array}$} & \multirow{2}{*}{2012} & $\mathrm{C} 1$ & $695.00 \mathrm{a}$ & 684 & 684 & 679 & 684 & 707 & 707 & 710 & 705 \\
\hline & & $\mathrm{O} 1$ & $694.88 \mathrm{a}$ & 692 & 688 & 694 & 697 & 693 & 697 & 698 & 700 \\
\hline & \multirow{2}{*}{2014} & $\mathrm{C} 1$ & $697.50 \mathrm{a}$ & 662 & 674 & 654 & 669 & 694 & 690 & 691 & 702 \\
\hline & & O1 & $703.50 \mathrm{~b}$ & 696 & 705 & 702 & 702 & 703 & 715 & 703 & 702 \\
\hline \multirow{4}{*}{$\begin{array}{l}\text { Thousand } \\
\text { grain } \\
\text { weight } \\
\text { g }\end{array}$} & \multirow{2}{*}{2012} & $\mathrm{C} 1$ & $47.10 \mathrm{a}$ & 48.1 & 48.5 & 47.1 & 47.9 & 47.5 & 45.7 & 46.7 & 45.3 \\
\hline & & $\mathrm{O} 1$ & $48.25 \mathrm{a}$ & 50.9 & 50.1 & 52.0 & 52.5 & 44.7 & 45.5 & 46.0 & 44.3 \\
\hline & \multirow{2}{*}{2014} & $\mathrm{C} 1$ & $47.19 \mathrm{a}$ & 47.2 & 50.0 & 47.5 & 48.1 & 45.7 & 46.3 & 46.3 & 46.4 \\
\hline & & $\mathrm{O} 1$ & $44.73 \mathrm{a}$ & 47.2 & 47.8 & 47.2 & 47.2 & 42.0 & 42.7 & 42.4 & 41.3 \\
\hline
\end{tabular}

Note. Means of traits of field trials with different letters are significantly different at the level of $p<0.05$.

Table 5. Restricted maximum likelihood (REML) estimates from mixed lineal model ( \pm standard error) for yield

\begin{tabular}{lc}
\hline \multicolumn{1}{c}{ Random effect variance } & $\begin{array}{c}\text { Yield } \\
\mathrm{t} \mathrm{ha}^{-1}\end{array}$ \\
\hline Cross & $0.02 \pm 0.14$ \\
Residual & $0.01 \pm 0.12$ \\
\hline \multicolumn{1}{c}{ Coefficient estimates } \\
\hline Intercept & $\mathbf{4 . 2 6} \pm \mathbf{0 . 1 3}$ \\
Cultivation site C1 & $\mathbf{- 0 . 3 9} \pm \mathbf{0 . 1 2}$ \\
Cultivation site O2 & $-0.03 \pm 0.12$ \\
Cultivation site O1 & $\mathbf{- 0 . 2 3} \pm \mathbf{0 . 1 2}$ \\
Testing environment O1 & $\mathbf{- 1 . 8 9} \pm \mathbf{0 . 1 2}$ \\
Year 2014 & $\mathbf{- 0 . 3 1} \pm \mathbf{0 . 1 2}$ \\
Cultivation site C1 $:$ testing environment O1 & $\mathbf{0 . 3 4} \pm \mathbf{0 . 1 6}$ \\
Cultivation site O2 : testing environment O1 & $-0.02 \pm 0.16$ \\
Cultivation site O1 : testing environment O1 & $-0.14 \pm 0.16$ \\
Cultivation site C1 $:$ year 2014 & $\mathbf{0 . 3 5} \pm \mathbf{0 . 1 6}$ \\
Cultivation site O2 $:$ year 2014 & $0.12 \pm 0.16$ \\
Cultivation site O1 $:$ year 2014 & $\mathbf{0 . 2 8} \pm \mathbf{0 . 1 6}$ \\
Testing environment O1 : year 2014 & $\mathbf{1 . 1 2} \pm \mathbf{0 . 1 6}$ \\
Cultivation site C1 $:$ testing environment O1 : & $\mathbf{- 0 . 3 9} \pm \mathbf{0 . 2 3}$ \\
year 2014 &
\end{tabular}

year 2014

Cultivation site $\mathrm{O} 2$ : testing environment $\mathrm{O} 1$ : year 2014

Cultivation site $\mathrm{O} 1$ : testing environment $\mathrm{O} 1$ : year 2014

$-0.12 \pm 0.23$

$0.12 \pm 0.23$

Note. Significant $(p<0.05)$ effects tested by Satterthwaites's approximation are in bold.

Crude protein content was significantly higher $(p<0.05)$ in organic testing environments compared to conventional testing environments. Starch content was slightly (but significantly) higher in the conventional testing environment in $2012(p<0.05)$, but no significant difference was observed in $2014(p>0.05)$. Volume weight was higher in 2014 in the organic testing environment $(p<0.05)$, but did not significantly differ among field trial environments in $2012(p>0.05)$. Thousand grain weight did not differ significantly $(p>0.05)$ between testing environments (Table 4). Environment of cultivation was not a significant factor for any of the measured grain quality traits. Crude protein content and starch content in grain were significantly affected by testing environment, testing year and their interaction. Thousand grain weight was significantly affected by testing year and interaction of testing year and testing environment. Grain volume weight was significantly affected by testing environment and interaction of testing year and testing environment (Table 6).

Investigation of genetic diversity and allelic composition showed that tested individuals from each of the parental varieties were monomorphic and homozygous at all loci. The parental varieties of one cross 'Anni' and 'Džiugiai' were not distinguishable at the loci Bmac0067 and WMC1E8, while the parental varieties of the other cross 'Primus' and 'Idumeja' were not distinguishable at the loci WMC1E8 and Bmag0173. However, the parental varieties of both crosses could be distinguished from each other using a combination of all the analysed markers. In addition, a possible homozygous null allele was detected at the locus Bmac0156 in the varieties 'Džiugiai' and 'Primus', as no amplification products were detected even after repeated genotyping.

All markers were polymorphic in all subpopulations with the exception of Bmac0067 in subpopulation $\mathrm{A} / \mathrm{Dz}-\mathrm{O} 1$ and marker WMC1E8 in subpopulations $\mathrm{A} / \mathrm{Dz}-\mathrm{O} 2, \mathrm{~A} / \mathrm{Dz}-\mathrm{C} 1$ and $\mathrm{P} / \mathrm{I}-\mathrm{O} 2$. In total, 53 alleles were identified over the nine loci. The average number of alleles per loci ranged from 1.889 (in subpopulation $\mathrm{A} / \mathrm{Dz}-\mathrm{C} 1$ ) to 3.556 (in $\mathrm{A} / \mathrm{Dz}-\mathrm{O} 1$ ) and was significantly lower $(\alpha=0.05)$ in $\mathrm{A} / \mathrm{Dz}-\mathrm{C} 1$ than in all other subpopulations, but the difference was not significant among the other three subpopulations. The average number of alleles with a frequency over 5\% was similar in all subpopulations, indicating that the lower number of alleles in subpopulation $\mathrm{A} / \mathrm{Dz}-\mathrm{C} 1$ was due to a decrease in rare alleles in comparison to the other subpopulations. The average values over all 
Table 6. Restricted maximum likelihood (REML) estimates from mixed lineal models ( \pm standard error) for protein content in grain, starch content in grain, thousand grain weight and volume weight

\begin{tabular}{ccccc}
\hline \multirow{2}{*}{ Random effect variance } & $\begin{array}{c}\text { Protein } \\
\mathrm{g} \mathrm{kg}^{-1}\end{array}$ & $\begin{array}{c}\text { Starch } \\
\mathrm{g} \mathrm{kg}^{-1}\end{array}$ & $\begin{array}{c}\text { Thousand grain weight } \\
\mathrm{g}\end{array}$ & $\begin{array}{c}\text { Volume weight } \\
\mathrm{g} \mathrm{L}^{-1}\end{array}$ \\
\hline Cross & $0 \pm 0$ & $0.83 \pm 0.92$ & $7.04 \pm 2.65$ & $119.29 \pm 10.92$ \\
Residual & $11.04 \pm 3.32$ & $7.69 \pm 2.77$ & $1.77 \pm 1.33$ & $60.08 \pm 7.75$ \\
& \multicolumn{2}{c}{ Coefficient estimates } \\
Intercept & $\mathbf{1 2 8 . 8 7} \pm \mathbf{0 . 9 9}$ & $\mathbf{6 0 6 . 1 3} \pm \mathbf{1 . 1 8}$ & $\mathbf{4 7 . 1 0} \pm \mathbf{1 . 9 3}$ & $\mathbf{6 9 5 . 0 0} \pm \mathbf{8 . 1 9}$ \\
Testing environment O1 & $\mathbf{1 6 . 5} \pm \mathbf{1 . 4 0}$ & $\mathbf{- 3 . 3 8} \pm \mathbf{1 . 3 9}$ & $1.15 \pm 0.67$ & $\mathbf{- 0 . 1 2 5} \pm \mathbf{3 . 8 8}$ \\
Year 2014 & $\mathbf{- 5 . 2 5} \pm \mathbf{1 . 4 0}$ & $\mathbf{9 . 0 0} \pm \mathbf{1 . 3 9}$ & $\mathbf{0 . 0 9} \pm \mathbf{0 . 6 7}$ & $-15.50 \pm 3.88$ \\
Testing environment O1 : year 2014 & $\mathbf{- 5 . 5} \pm \mathbf{1 . 9 7}$ & $\mathbf{6 . 0 0} \pm \mathbf{1 . 9 6}$ & $\mathbf{- 3 . 6 1} \pm \mathbf{0 . 9 4}$ & $\mathbf{2 4 . 1 2} \pm \mathbf{5 . 4 8}$ \\
\hline
\end{tabular}

Note. Significant $(p<0.05)$ effects tested by Satterthwaites's approximation are in bold.

loci of the other genetic diversity indices (the number of effective alleles, Shannon's information index and expected heterozygosity) were all similar between the four subpopulations (Table 7).

The major allele frequencies in each subpopulation were as expected from the parental variety genotyping results. The observed heterozygosity was low, ranging from 0.005 in subpopulation $\mathrm{A} / \mathrm{Dz}-\mathrm{C} 1$ to 0.035 in subpopulation A/Dz-O1 (average 0.019) (Table 6). The frequencies of alleles not found in the parental varieties were also low, ranging from 0.005 to 0.059 (average 0.018) over all four subpopulations, indicating that the level of pollination from outside sources and/or mechanical seed admixture was low.

Table 7. Genetic diversity indices of analysed spring barley subpopulations

\begin{tabular}{ccccccc}
\hline Subpopulation & $\mathrm{Na}$ & $\mathrm{Na}$ Freq. $\geq 5 \%$ & $\mathrm{Ne}$ & $\mathrm{I}$ & $\mathrm{He}$ & Ho \\
\hline $\mathrm{P} / \mathrm{I}-\mathrm{O} 1$ & $3.000 \mathrm{a} \pm 0.408$ & $1.778 \pm 0.222$ & $1.633 \pm 0.173$ & $0.525 \pm 0.120$ & $0.323 \pm 0.077$ & $0.012 \pm 0.011$ \\
$\mathrm{P} / \mathrm{I}-\mathrm{C} 1$ & $3.444 \mathrm{a} \pm 0.242$ & $1.667 \pm 0.167$ & $1.731 \pm 0.165$ & $0.593 \pm 0.106$ & $0.366 \pm 0.074$ & $0.023 \pm 0.014$ \\
\hline $\mathrm{A} / \mathrm{Dz}-\mathrm{O} 1$ & $3.556 \mathrm{a} \pm 0.530$ & $1.778 \pm 0.222$ & $1.779 \pm 0.192$ & $0.598 \pm 0.140$ & $0.363 \pm 0.086$ & $0.035 \pm 0.019$ \\
\hline $\mathrm{A} / \mathrm{Dz}-\mathrm{C} 1$ & $1.889 \mathrm{~b} \pm 0.261$ & $1.667 \pm 0.167$ & $1.649 \pm 0.163$ & $0.466 \pm 0.117$ & $0.328 \pm 0.082$ & $0.005 \pm 0.005$ \\
\hline
\end{tabular}

Note. $\mathrm{Na}$ - average number of alleles per locus, $\mathrm{Na}$ Freq. $\geq 5 \%$ - number of alleles with frequency $\geq 5 \%, \mathrm{Ne}-$ effective number of alleles, I - Shannon's information index, He - expected heterozygosity, Ho - observed heterozygosity; means of number of alleles with different letters are significantly different at the level of $p<0.05$.

Analysis of the major allele frequencies indicated that the majority of loci did not significantly differ from the expected ratio of 1:1, which would be expected from an advanced generation of a simple cross. In the cross 'Anni'/'Džiugiai', the allelic ratio at locus Bmag0173 was significantly different from $1: 1$, where the 'Džiugiai' allele was in a higher proportion in both subpopulations. In the cross 'Primus'/'Idumeja', the 'Idumeja' allele of locus Bmag0125 was significantly higher in both subpopulations, the 'Idumeja' allele of locus Bmag0135 was significantly higher in subpopulation $\mathrm{P} / \mathrm{I}-\mathrm{C} 1$, while the 'Primus' allele of locus Bmac0032 was significantly higher in subpopulation P/I-O1 and the 'Primus' allele of locus Bmag0353 was significantly higher in subpopulation $\mathrm{P} / \mathrm{I}-\mathrm{C} 1$. The loci that were monomorphic between the parental varieties of each cross were also monomorphic in the subpopulations (their ratio was not significantly different from 1). The locus Bmac0156 possibly had a homozygous null allele in the varieties 'Džiugiai' and 'Primus', as described previously. It is also possible that a heterozygous null allele was present at this locus in the varieties 'Anni' and 'Idumeja', as the genotyped subpopulations had a high number of individuals with missing data, which could indicate the presence of a homozygous null allele. These individuals did not have missing genotypes at the other analysed loci, indicating that DNA quality or PCR inhibition was not a significant factor.

Principal coordinate analysis (PCoA) indicated that the parental varieties of each cross were well differentiated, and the individuals within each subpopulation did not show any preferential clustering with either of the parental varieties (Figs. 1-2).

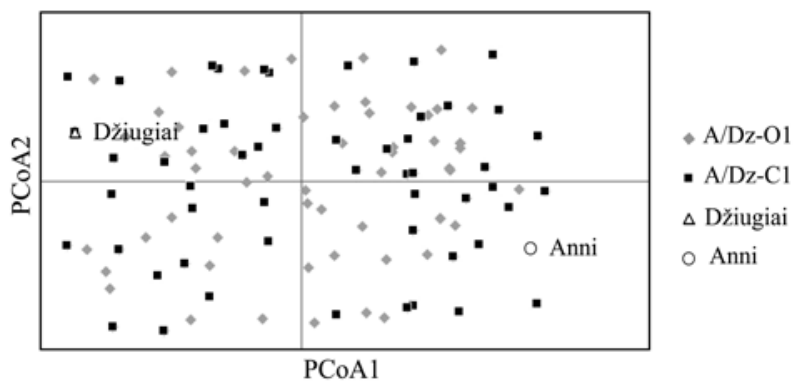

Figure 1. Principal coordinate analysis ( $\mathrm{PCoA})$ of the SSR data of 95-96 individuals of two subpopulations derived from cross 'Anni'/'Džiugiai' cultivated in parallel for six seasons in organic and conventional conditions

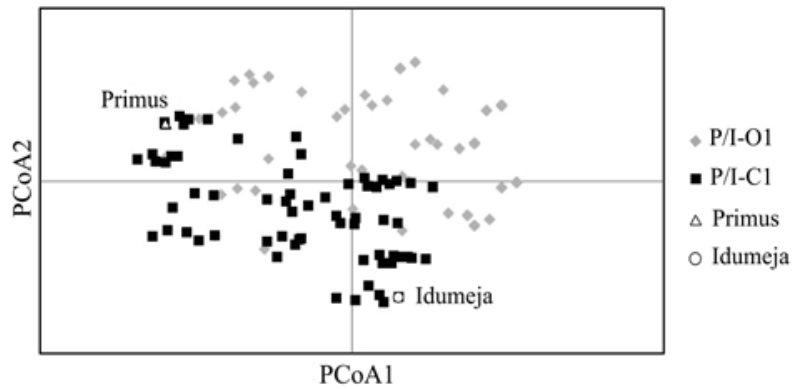

Figure 2. Principal coordinate analysis (PCoA) of the SSR data of 95-96 individuals of two subpopulations derived from cross 'Primus'/'Idumeja' cultivated in parallel for six seasons in organic and conventional conditions 
Pairwise comparison of genetic identity between subpopulations shows that they are clustered together by their origin. Subpopulations originating from cross $\mathrm{P} / \mathrm{I}$ are differentiated from subpopulations derived from cross A/Dz (Table 8).

Table 8. Pairwise subpopulation matrix of Nei genetic identity

\begin{tabular}{ccccc}
\hline Subpopulation & A/Dz-O1 & A/Dz-C1 & P/I-O1 & P/I-C1 \\
\hline A/Dz-O1 & 1.000 & & & \\
A/Dz-C1 & 0.995 & 1.000 & & \\
P/I-O1 & 0.455 & 0.443 & 1.000 & \\
P/I-C1 & 0.470 & 0.457 & 0.980 & 1.000 \\
\hline
\end{tabular}

The highest genetic identity $(0.995)$ was found between $\mathrm{A} / \mathrm{Dz}-\mathrm{O} 1$ and $\mathrm{A} / \mathrm{Dz}-\mathrm{C} 1$ and between $\mathrm{P} / \mathrm{I}-\mathrm{O} 1$ and P/I-C1 (0.980) indicating that the subpopulations of the same origin were genetically similar, as expected according to Figure 2. A slightly larger differentiation between subpopulations of cross $\mathrm{P} / \mathrm{I}$ was observed if compared to cross $\mathrm{A} / \mathrm{Dz}$.

\section{Discussion}

To the best of our knowledge, the present study is the first that analyses the effect of cultivation of the same bi-parental populations in organic and conventional farming systems. We cultivated two populations derived from the crosses 'Primus'/'Idumeja' and 'Anni'/'Džiugiai' in parallel in two organically and two conventionally managed sites resulting in eight subpopulations. In the $6^{\text {th }}$ and $8^{\text {th }}$ cultivation years we tested field performance of all eight subpopulations in one organic and one conventional site, and genotyped two subpopulations per cross in the $7^{\text {th }}$ cultivation year.

Highest yields were observed in conventional conditions, as expected in cereals according to metaanalysis performed by Seufert et al. (2012). Protein content in both test years was higher in organic growing conditions demonstrating better nitrogen uptake and use by plants. In contrast to mineral fertilization before sowing in conventionally managed fields, green manure was grown as a pre-crop in organic fields, ensuring that nutrients became available gradually over the vegetation period, whereas availability of mineral fertilizer could be negatively affected to a greater extent due to dry soil conditions immediately after sowing (2014) and extremely wet weather after sowing (2012 and 2014). Other grain quality traits were less affected by growing conditions and either no difference in trait values for organic versus conventional growing systems was observed, or significant differences were observed only in one testing year.

Only subpopulations originating from $\mathrm{O} 2$ site were never the lowest yielding ones among the four subpopulations from the same cross in any of the testing environments. The subpopulation $\mathrm{P} / \mathrm{I}-\mathrm{O} 2$ showed a tendency to benefit from change from organic to conventional growing conditions in both field trial years, and showed higher yields than other subpopulations from the same cross tested in the $\mathrm{C} 1$ site. Probably this tendency might mean, if natural selection has occurred in very fluctuating environments (some of the cultivation years in $\mathrm{O} 2$ site were with extremely low yield level), the population can better adapt to further changes in environmental or agronomic conditions.

Study of Verhoeven et al. (2008) shows that first trait recognised to respond to natural selection in annual plants is flowering time. In our study flowering time was heterogeneous within the subpopulations and no discernible tendencies were observed.

Rapid adaptation in crop plants has mostly been studied with regard to climate change. Contrasting results between response due to elevated $\mathrm{CO}_{2}$ and temperature has been recorded: Alemayehu et al. (2013) found that over four generations barley yields do not increase; however, Frenck et al. (2013) documented that yield of oilseed rape has the potential to improve under natural selection over four generations. Both barley and oilseed rape in the previously mentioned studies did not adapt to elevated temperature over the course of the studies, but both studies employed a limited number of varieties (two and four, respectively). Long term studies over 28 generations in wild wheat and barley subjected to changing climatic conditions in Israel showed an influence on earliness and SSR allelic composition in 20 populations (Nevo et al., 2011). A 10 year study of two wheat CCPs with six derived subpopulations cultivated in different parts of France showed that first changes in agro-morphological traits were observed after six years of cultivation. The first observed trait to change was plant height, which can be explained by competition for light and presence of polymorphic dwarfing loci, followed by earliness (Enjalbert et al., 2011). In our study we found a significant effect of subpopulation cultivation site on grain yield but not on grain quality traits; however, yield differences between subpopulations were minor. It must be taken into account that bi-parental populations have much lower level of diversity than CCPs and the subpopulations in this study were compared after only five and seven years of cultivation, in addition, the cultivation sites were close to each other therefore meteorological conditions were similar each year.

We observed that each pair of subpopulations derived from the two crosses was genetically similar. They had high Nei genetic identity index $(>0.95)$ and each pair clustered together in PCoA. This is in agreement with Rousselle et al. (2011) who observed no loss of within population diversity and little genetic divergence of sub-populations in wheat populations cultivated over 12 generations. We found that in bi-parental subpopulations there were more alleles at most loci than in the parental varieties. This could be explained by a small outcrossing rate of barley and possible mechanical admixtures of seeds of other varieties. A similar outcrossing rate was detected in a study of gene flow from modern barley varieties to landrace populations (Bellucci et al., 2013). Given the fact that only two parental varieties were used to create each population, high genetic diversity was not expected. PCoA analysis indicated that individuals of the subpopulations were intermediate between parental varieties, and no clustering with only one of the parents of each cross was observed.

In general, there was no preferential contribution of alleles from one parent to the subpopulations. The few loci that were statistically different from the expected $1: 1$ allelic ratio could possibly be due to genetic drift. The utilised SSR markers were unlinked to each other, and some of them were associated with QTLs for reaction to Fusarium gramineum, plant height, kernel weight and days to heading (database GrainGenes, http://wheat. pw.usda.gov/GG2/index.shtml). However, these traits were not assessed in our study. The utilised markers were not chosen on the basis of association with a particular trait, and no association of markers and traits was detected. The use of a larger number of DNA markers may have enabled identification of genomic regions that were preferentially inherited from either parental variety. 
However, given there was relatively weak selection pressure on these populations - only natural selection, no phenotypic or bulk selection, and the number of generations was relatively small, it is possible that the inheritance of traits and alleles has been balanced between the parental varieties. In addition, the relatively small number of generations since the initial cross would not have allowed for recombination to disrupt large linkage blocks inherited from each parent, therefore, a relatively small number of markers on each chromosome could be sufficient to detect preferential inheritance of genomic regions from one parental variety. The advantages of these segregating populations could be more pronounced under more severe selective pressures, or over a larger number of generations, allowing increased genetic recombination and adaptation to local environmental conditions.

It is possible that the significant decrease in the number of alleles identified in subpopulation $\mathrm{A} / \mathrm{Dz}-\mathrm{C} 1$ was influenced by an unusually high incidence of barley yellow dwarf virus in 2010 particularly at the $\mathrm{C} 1$ site. Data on infection rate of the parents shows that variety 'Anni' was the most infected (score 5 from range 0-9), variety 'Idumeja' had score 2 , and varieties 'Primus' and 'Džiugiai' did not have the virus symptoms. There was no large decrease in the frequency of SSR marker alleles from the parental variety 'Anni' in the subpopulation and the decrease in the number of alleles was due to loss of low frequency alleles. This could be due to relatively lower disease resistance in the cross-pollinated or admixed individuals, or could alternatively be a result of a slight genetic bottleneck due to the disease, reducing the number of individuals contributing to the next generation.

The relatively low level of genetic variation resulting from the use of only two genetically homogeneous varieties in the creation of the bi-parental crosses might restrict options for genetic adaptation to growing environments. It cannot be ruled out that the use of other or more varieties, or more genetically diverse material (landraces, CCPs) might have resulted in faster adaptation; therefore a larger number of genotypes should be involved to determine the influence of increased genetic and trait diversity. Also a larger number of generations under more severe selection pressure could possibly lead to increased adaptation to certain growing conditions.

Asignificanteffectofcultivationenvironmentwas found in the case of grain yield. However, it is impossible to differentiate if the reason for this was adaptation to the particular environment or an environmental effect of the seed production site (cultivation site in previous season) or a combination of these two factors. Environmental conditions of parental plant cultivation can influence seed and seedling performance (Donohue, 2009).

\section{Conclusions}

1. The results of the field trials indicated that while there were some significant differences in yield between subpopulations derived from organic and conventional cultivation sites, the grain quality traits were not similarly influenced. The genetic analyses indicated that there was little or no significant differentiation between the two pairs of analysed subpopulations.

2. Short-term cultivation of two barley populations in organic and conventional growing conditions did not significantly change genetic diversity or allelic composition as assessed by simple sequence repeat (SSR) markers - each pair of subpopulations derived of two bi-parental populations was genetically similar. They had high Nei genetic identity index and each pair overlapped in principal coordinate analysis (PCoA). However, a small level of differentiation was observed for one pair of subpopulations and one of the populations had significantly lower number of alleles.

3. Each parental variety contributed a similar proportion of alleles to the subpopulations; therefore we can conclude that there was no major selection pressure for or against the genetic contribution of one particular parental variety in the derived subpopulations.

4. The agronomic and genetic similarities between the analysed spring barley subpopulations suggest that populations derived from simple two parent crosses and grown in organic and conventional conditions are due to a number of different factors, including the low level of phenotypic plasticity of barley, the limited genetic diversity in the parents (and the low outcrossing rate of barley), low selection intensity on the subpopulations during the period of cultivation.

5. Future directions for further investigation include the use of composite cross populations (CCPs) to increase the initial genetic diversity of derived populations, cultivation of populations in conditions with more intense selective pressures, and the assessment of additional agronomic or phenotypic traits, which may be more rapidly influenced by divergent selection between subpopulations.

\section{Acknowledgments}

Financial support for this study was provided by the Latvian Council of Science project No. 155/2012 "Genetically diverse varieties for environmentally friendly agriculture - study on advantages and breeding strategies".

Received 10082016

Accepted 30012017

\section{References}

Alemayehu F. R., Frenck G., van der Linden L., Mikkelsen T. N., Jørgensen R. B. 2013. Can barley (Hordeum vulgare L. s.1.) adapt to fast climate changes? A controlled selection experiment. Genetic Resources and Cron Evolution. 61 (1): 151-161 https://doi.org/10.1007/s10722-013-0021-1

Barrett R. D., Schluter D. 2008. Adaptation from standing genetic variation. Trends in Ecologv and Evolution, 23 (1): 38-44 https://doi.org/10.1016/j.tree.2007.09.008

Bates D., Maechler M. 2013. Ime4: linear mixed-effects models using S4 classeds. $R$ package <http://cran.r-project.org/ web/packages/lme4/index.html $>$

Bellucci E., Bitocchi E., Rau D., Nanni L., Ferradini N., Giardini A., Rodriguez M., Attene G., Papa R. 2013. Population structure of barley landrace populations and geneflow with modern varieties. PLoS One, 8 (12): e83891 https://doi.org/10.1371/journal.pone.0083891

Bertholdsson N. O., Weedon O., Brumlop S., Finckh M. R. 2016. Evolutionary changes of weed competitive traits in winter wheat composite cross populations inorganicand conventional farming svstems. Euronean Journal of Agronomy, 79: 23-30 https://doi.org/10.1016/j.eja.2016.05.004

Donohue K. 2009. Completing the cycle: maternal effects as the missing link in plant life histories. Philosophical Transactions of the Royal Society of London B: Biological Sciences, 364 (1520): 1059-1074 https://doi.org/10.1098/rstb.2008.0291

Edwards K., Johnstone C., Thompson C. 1991. A simple and rapid method for the preparation of plant genomic DNA for PCR analysis. Nucleic Acids Research, 19: 1349 https://doi.org/10.1093/nar/19.6.1349

Enjalbert J., Dawson J. C., Paillard S., Rousselle Y., Thomas M., Goldringer I. 2011. Dynamic management of crop diversity: from an experimental approach to on-farm conservation. Comptes Rendus Biologies, 334: 458-468 https://doi.org/10.1016/j.crvi.2011.03.005 
Fess T. L., Kotckon B. J., Benedito V. A. 2011. Crop breeding for low input agriculture: a sustainable response to feed a growing world population. Sustainability, 3 (10): 1742-1772 https://doi.org/10.3390/su3101742

Frenck G., van der Linden L., Mikkelsen T. N., Brix H., Jørgensen R. B. 2013. Response to multi-generational selection under elevated $\left[\mathrm{CO}_{2}\right]$ in two temperature regimes suggests enhanced carbon assimilation and increased reproductive output in Brassica napus L. Ecology and Evolution, 3: 1163-72 https://doi.org/10.1002/ece3.523

Knapp S., Snape J., Döring T. F., Wolfe M. S., Griffiths S. 2013. Genetic analysis of evolving winter wheat populations reveals reversion to wild type. Proceedings of the International Symposium on Evolutionary Breeding in Cereals. Birmingham, United Kingdom, p. $10<$ http:// orgprints.org/22440/>

Kuznetsova A., Brockhoff P. B., Cristensen R. 2013. lmerTest: tests for random and fixed effects for linear mixed effect models (lmer objects of lme34 package). $R$ package, version 1.0-2 <http://cran.r-project.org/web/packages/ lmerTest/index.html>

Li X., Li H., Zou Q., Li Z., Wang M., Xu C. 2014. What has been neglected in the green revolution? Developing crop poly-genotype varieties for improving (intra-variety) genetic diversity in Agriculture. Open Journal of Ecology, 4: 394-410 https://doi.org/10.4236/oje.2014.47035

Macaulay M., Ramsay L., Powell W., Waugh R. 2001. A representative, highly informative "genotyping set" of barlev SSRs. Theoretical and Applied Genetics, 102: 801-809 https://doi.org/10.1007/s001220000487

Mercer K. L., Perales H. R. 2010. Evolutionary response of landraces to climate change in centers of crop diversity. Evolutionary Applications. 3 (5-6): 480-493 https://doi.org/10.1111/j.1752-4571.2010.00137.x

Murphy K., Lammer D., Lyon S., Carter B., Jones S. S. 2005. Breeding for organic and low-input farming systems: an evolutionary-participatory breeding method for inbred cereal grains. Renewable Agriculture and Food Systems, 20: 48-55 https://doi.org/10.1079/RAF200486
Nevo E., Fu Y., Pavlicek T., Khalifa S., Tavasi M., Beiles A. 2011. Evolution of wild cereals during 28 years of global warming in Israel. Proceedings of the National Academy of Sciences. 109: 3412-3415 https://doi.org/10.1073/pnas.1121411109

Østergård H., Finckh M. R., Fontaine L., Goldringer I., Hoad S. P., Kristensen K., Lammerts E. T., Bueren V., Mascher F., Wolfe M. S. 2009. Time for a shift in crop production: embracing complexity through diversity at all levels. Journal of Agricultural and Food Chemistry, 89: $1439-1445$ https://doi.org/10.1002/jsfa.3615

Peakall R., Smouse P. E. 2012. GenAlEx 6.5: genetic analysis in Excel. Population genetic software for teaching and research-an undate. Bioinformatics. 28: 2537-2539 https://doi.org/10.1093/bioinformatics/bts460

Raggi L., Ceccarelli S., Negri V. 2015. Evolution of a barley composite cross-derived population: an insight gained by molecular markers. Journal of Agricultural Science. 154 (1): 23-39 https://doi.org/10.1017/S0021859614001269

Raquin A. L., Brabant P., Rhone B., Balfourier F., Leroy P., Goldringer I. 2008. Soft selective sweep near a gene that increases plant height in wheat. Molecular Ecology, 17: 741-756 https://doi.org/10.1111/j.1365-294X.2007.03620.x

Rousselle Y., Thomas M., Galic N., Bonnin I., Goldringer I. 2011. Inbreeding depression and low between-population heterosis in recently diverged experimental populations of a selfing snecies. Heredity, 106 (2): 289-299 https://doi.org/10.1038/hdy.2010.72

Seufert V., Ramankutty N., Foley J. A. 2012. Comparing the yields of organic and conventional agriculture. Nature, 485: 229-232 https://doi.org/10.1038/nature11069

Verhoeven K. J. F., Poorter H., Nevo E., Biere A. 2008. Habitatspecific natural selection at a flowering-time QTL is a main driver of local adaptation in two wild barley populations. Molecular Ecologist. 17: 3416-3424

https://doi.org/10.1111/j.1365-294x.2008.03847.x

ISSN 1392-3196 / e-ISSN 2335-8947

Zemdirbyste-Agriculture, vol. 104, No. 2 (2017), p. 157-164

DOI $10.13080 / \mathrm{z}-\mathrm{a} .2017 .104 .020$

\title{
Vasarinio miežio hibridinių populiacijų reakcija ị auginimą taikant ekologinę ir tradicinę žemdirbystès sistemas
}

\author{
I. Mežaka ${ }^{1}$, I. Ločmele ${ }^{1}$, D. Ruņgisis ${ }^{2}$, L. Legzdiņa ${ }^{1}$ \\ ${ }^{1}$ Latvijos žemès ūkio išteklių ir ekonomikos institutas \\ ${ }^{2}$ Latvijos valstybinis miškotyros institutas „Silava“
}

\section{Santrauka}

Ekologinis ūkininkavimas tampa vis svarbesnis, todèl didèja ir poreikis veislių, pasižyminčių stabiliu derliumi bei tinkamų auginti ekologinėmis sąlygomis. Heterogeniškos savidulkių augalų populiacijos yra pranašesnès už šiuo metu auginamas homogenines veisles. Tyrimo tikslas - palyginti grūdų derlių, jų kokybès požymius ir genetinę ịvairovę dviejų vasarinio miežio (Hordeum vulgare L.) populiacijų, augintų ir tirtų šeštoje-aštuntoje palikuonių kartoje.

Populiacijos, sukurtos taikant paprastus kryžminimus, $\mathrm{F}_{4}$ kartoje buvo suskirstytos ị subpopuliacijas ir tuo pat metu augintos ekologinio bei tradicinio auginimo vietose penkias kartas. Siekiant nustatyti, ar turi išskirtinių grūdų derliaus ir kokybės savybių, visos populiacijos buvo palygintos bendrame lauko bandyme vienoje ekologinio ir vienoje tradicinio auginimo vietose. Kiekvieno kryžminimo dviejų subpopuliacijų genetinè ịvairovẻ tirta septintą auginimo sezoną naudojant devynis paprastujų pasikartojančių sekų (PPS) žymeklius.

Mišraus modelio taikymas parodè, kad auginimo aplinka buvo reikšminga grūdų derliui, tačiau neturèjo ịtakos jų kokybės požymiams. Subpopuliacijų, gautų per šešių kartų kryžminimus, auginimas tuo pačiu metu taikant ekologinę ir tradicinę žemdirbystès sistemas, reikšmingai nepakeitė genetinès alelių sudèties, ịvertintos PPS žymekliais - kiekviena to paties kryžminimo subpopuliacijų pora buvo panaši abiejose aplinkose, tačiau viena populiacija parodė nedidelị nuokrypị. Nustatyta, kad abi tėvinès veislès prisidèjo panašiu kiekiu alelių, o tai rodo, kad selekciniu atžvilgiu nè viena iš tèvinių veislių nebuvo pranašesnè už kitą.

Reikšminiai žodžiai: genetinè adaptacija, Hordeum vulgare, kryžminimas, natūrali atranka, PPS žymekliai. 